\title{
IMAPS ’99視察団報告
}

\section{IMAPS '99 Inspecting Party Reports}

レポーター：中祖 昭士

(日立化成工業)

1999年10月26日〜28日, 米国ChicagoのHilton \& Towers HotelにおいてIMAPS'99が開催された。本年度もエレクト ロニクス実装学会の企画で視察団が結成され, 現地での参 加を含め 9 人が参加した。この視察団プログラムにはシン ポジウムへの参加のほかにTechSearch International社の バーダマン女史によるパッケージング技術の動向調査報告 セミナー，抄よびシンポジウム終了翌日（29日）に企業訪 問が企画されていた。視察団への参加の利点はこのシンポ ジウムに初めて参加した人でも団長を含む先輩諸氏の経験 と知識を享受できること，そしてこのレポートで報告する 企業訪問がある。若手の教育を兼初てシンポジウムへの参 加を企画されている企業の方が, 今後この視察団を利用さ れるのも有効な方法と思われる。かく言う私は若手ではな いが今回初めて参加したIMAPSビギナーであり, 今回の 視察旅行中には二瓶早稲田大学客員教授団長をはじめ ASET電子SI技術研究部長の盆子原さん, 企業訪問先のア ポイントをとっていただいた東レエンジニアリング社の永 松さん, ThreeBond社の大石さん, 他参加者の方々に多 くのお世話をいただき有意義な視察旅行を経験することが できた。これは私のみならず参加者の皆さんが等しく感じ られたことと思う。

(1) 3-Com社見学

今回の企業訪問は3-Com社とMotorola社である。最初 (29日午前中) に3-Com社を見学した。3-Com社の製品に はポピュラーなパソコン用LANカードがあるので, パソ コンユーザの方は “3-Com”のロゴをご存知のことと思う。 3-Com社は1979年に創立され，ネットワークコミュニケー

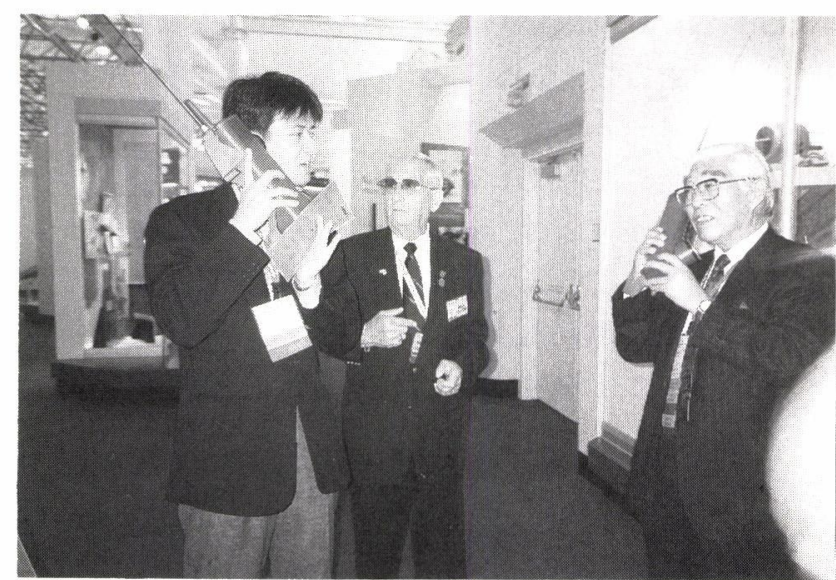

写真1。展示されている初期の重い携帯電話を使用してみる視察団 参加者
ション関係の多数の携帯機器および装置を製造販売してい る。具体的にはPalm Computing機器, Network Interface Cards, グループ内パソコン間の接続用Hubs，グループ間 の高速接続用Switches，ネットワーク間接続用Routersな どである。

最初にSwitchesあるいはRouter用と思われるマザーボ ードへの部品自動実装ラインを見学した。この部品実装ラ インには日本の著名なメーカの装置が使用されていた。ピ ン数のかなり多いCSPも実装されており案内者の様子でも かなり実装技術に自信を持っている様子であった。実装う インの所々に歩留まりの目標值と実際值を示すディスプレ 一が設置されており，作業者の努力を促す工夫もなされて いた。Palm Computing機器の実装および組み立てライン ではまだかなり手作業が残されていた。Switchesあるい はRouterの組み立てラインも見学した。日本への出荷が かなりあるらしく, 私たちを顧客とみなしてか, 予定時間 をオーバするほど親切に案内していただいた。

(2) Motorola社工場見学

Motorola社正面建物の前面には広大な芝生の庭が広が っており，その庭にはゴルフ場の池超えショートホール並 みの大きな池がある。と言ってもゴルフのプレー時のよう なストレスを与えるものではなく，訪問する私たちをおお らかな気持ちにさせてくれる雲囲気のものである。訪問し たとき, ちょうど, 渡り鳥と思われるたくさんの鳥たちが 遊んでおり，Motorola社が自然との共生に配慮している ことが感じられた。同時にスケールや文化の違いも印象づ けられた。

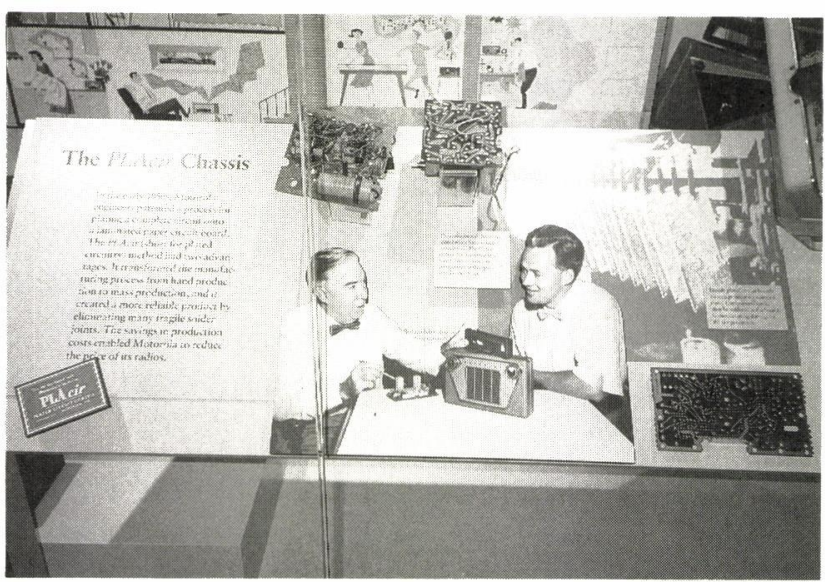

写真2. 初期のプリント配線板（1950年代の始め) 


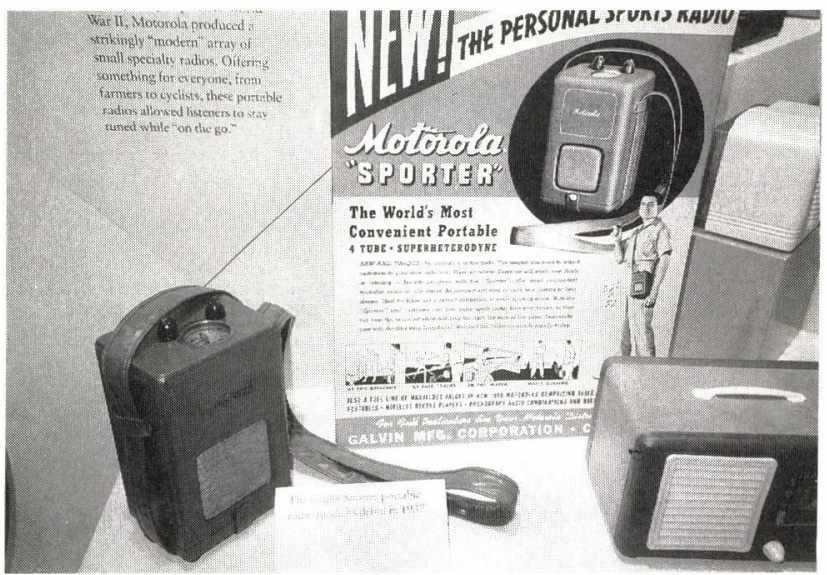

写真3. 1937年にデビューしたポータブルラジオ

Motorola社ではセラミック関係の実装ラインを簡単に 見学した後, 電話等のNetwork Systemを顧客に納入する 前に行うTeachingを目的にしたものと思われるSectionを 案内された。詳細は理解できなかったが, Network Systemの受け渡しをスムーズに行うためにこのような Sectionが設けられたものと思われた。Motorola社が顧客 満足度の向上を重要視していることが印象づけられた。

(3) Motorola社博物館 (Motorola Museum of Electronics）見学

次に同じ敷地内（と言っても広大な敷地である）の Motorola博物館を見学した。この博物館は1990年代に創 られたものであり，まだ新しい。20世紀におけるエレクト ロニクス産業の発展とともに歩んできたMotorola社の歴 史を展示したものである。実物が展示されており，一部で はそれに触れることが可能である。20世紀が終わろうとし ている現在, 社会生活や国家間のありかたが急速に変化し つつある。変化後の社会システムを支える最も大きな技術 がデジタル情報ネットワークと言える。Motorolaは情報 関連分野を巨大なコア技術にしている。1940年代に製造し たMotorola製の携带電話が展示されており（それはまだ 通信可能なものである)，それを使用してみるときわめて 重く大きいものであることに驚いた（写真 1 参照, あまり

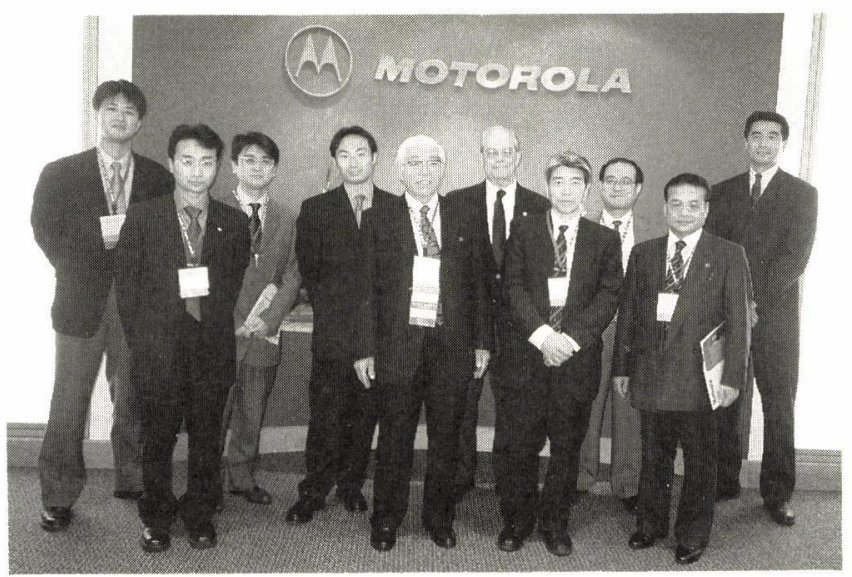

写真4. Motorola Museumでの視察団参加者の皆さん

にも重いので思わず笑ってしまう）。また初期（1950年代 の始め)のプリント配線板が展示されていた(写真 2 参照)。 今日ではビルドアップ多層配線板の時代に移っており, 今 それを見ると超低密度プリント配線板なのでその価值を小 さくとらえてしまう。しかしこれが登場した時代には, 最 先端技術であったはずのものである。

今日の高性能な製品群は一分野の技術のみで達成された ものはなく, 複数の技術が融合されて実現されたものであ る。技術情報の有機的な結びうきが情報のネットワーク化 によって促進され，工業技術の発展が一層速まる時代にな ってきたと言える。実物をふんだんに用いた展示からエレ クトロニクス産業発展の歴史を体系的に認識することがで きる有益な見学であった。同時に, 今後の技術発展の動向 や自社の技術のあり方についても考えさせられる良い機会 であった。写真 4 はMotorola Museum見学後の参加者全 員の記念写真である。

次回以降もエレクトロ二クス実装学会においてこのよう な視察団が企画され, 多くの若い方々が参加できる機会が 設けられることを期待したいと思います。最後に本視察団 を企画された方々, 視察団長としてご指導くださった二瓶 早稲田大学客員教授に㧍礼を申し上げます。 